\author{
現代ロシア文学における芸者の表象 \\ —オルガ・ラゾレワの『ロシア人芸者』を中心に— \\ リンダ・ガルワーネ \\ (大阪大学文学研究科博士後期課程)
}

\title{
Representation of Geisha in Contemporary Russian Literature: Olga Lazoreva's Russian Geisha
}

\author{
GaLVANE, Linda \\ Graduate Student, Graduate School of Letters, Osaka University
}

\begin{abstract}
After the collapse of the Soviet Union new enthusiasm for Japan, often dubbed "New Japonism," emerged in Russia. Along with Murakami Haruki, manga and anime, etc., geisha, one of the main representations of Japan abroad since the end of the $19^{\text {th }}$ century, evoked a fresh interest. The new edition of the Russian translation of Loti's Madame Chrysanthème, the translation of Nakamura Kiharu's biographical work, the popularity of Arthur Golden's novel as well as the success of the movie, Sayuri, based on the novel, are just few examples of this revived interest in geisha. Moreover, some contemporary Russian writers themselves created works, incorporating Japanese themes in their works, including the representation of geisha. Olga Lazoreva's trilogy, Russian Geisha, is a story about a Russian girl who undertakes the training as a geisha after her lover dies in connection with the Aum Shinrikyo sect and the Tokyo sarin subway incident. It also is a work, created under New Japonism in Russia and, as reflected in the title, represents geisha in her own way. Lazoreva was invited to write a novel about geisha by a publishing house in the light of popularity of Golden's novel, The Memoirs of Geisha, and its film version in Russia. Thus at the first glance it would seem that Lazoreva merely reproduced the theme of geisha, found in other works. Besides, even though Lazoreva in her work constantly stresses the fact that geisha is not a prostitute, the explicit descriptions of sexuality in the work, would create a contrary impression that this trilogy is just another representation of exotic Japanese sexuality as exotic one.

The fact that geisha, represented in Lazoreva's work, is of mixed origins plays an important role. By creating an untypical geisha character, closely connected to Russia, Lazoreva's work not merely represents the exotic Other, but, through the protagonistgeisha, being both Japanese and Russian, also discloses a concealed self-representation of the Russians. This paper is thus an attempt to explore the representation of geisha,
\end{abstract}

Keywords: Lazoreva, contemporary Russian literature, Japonism, exoticism, geisha 
its peculiarities and significance in contemporary Russian literature by focusing on the trilogy Russian Geisha, which would shed a new light on the construction of the modern Russian subjectivity itself.

The work will analyze the representation of geisha focusing on the following three points: firstly, the analysis of the way Lazoreva operates with the stereotype of geisha, often perceived as a prostitute; secondly, the comparison of the representation of geisha in Lazoreva's work to the representation of Russian women in general in the context of some other contemporary Russian literary works, such as Chapaev and Void by Viktor Pelevin and The Intergirl by Vladimir Kunin, the works that describe Russian women in their peculiar ways. Lastly, on the basis of these analyses, this paper will try to clarify the relevance of Russian Geisha to the socio-economic situation of the post-Perestroika and post-Soviet Russia and to its gender politics.

\section{は じめに}

ロシアではペレストロイカ以降，村上春樹など現代作家の作品の翻訳，漫画，アニメ，才 タク文化の流行に見られるよらに，「ニュー・ジャポニスム」ともいえるよらな日本への興味 の復活が最近, 見られ, その中で, 19 世紀後半から日本を「代表する」モチーフであった芸 者・ムスメも改めて重要なテーマとなっている。こうした傾向は, ロティ（Pierre Loti）の 『お菊さん』(Madame Chrysanthème, 1887）の再版（1992）(1)，アーサー・ゴールデン（Arthur Golden)の『さゆり』(Memoirs of Geisha, 1997） (2), 中村喜春の『江戸っ子芸者一代記』(1983）(3) の翻訳などからも見て取れるであろら。日本への関心の再来を背景にして, 現代日本文学作品 の翻訳が次々, 行われているだけでなく, 日本を作品に描き出すロシア人の作家の活躍も顕著 な現象となっている。2006 年から出版されたオルガ・ラン゙レワ（Ольга Лазорева）(1957-）(4) の『ロシア人芸者の回想録』(Мемуары русской гейши) (5) もとの一つである。

作品の構成の中心となるのは, 主人公のロシア人女性とオウム真理教の信者との関係であ り，探偵小説風だが，作品の題名からも分かるように，謎解きょりは芸者のエキゾチズムが大

(1) Лоти, Пьер, Госпожа Хризантема; Роман одного спаги, Москва: Конкорд, 1992. その後 2004 年に も再版されている。Лоти, Пьер, Госпожа Хризантема, Москва: Рипол классик, 2004.

(2) Голден, Артур, Мемуары гейши, Москва: Контора Домби, 2001.

(3) Накамура, Кихару, Исповедь гейши, Москва: Эксмо-Пресс, 2001. ロシア語訳は日本語からでなく, ドイッ語訳 Kiharu—Memoiren einer Geisha, Bergisch Gladbach: Bastei Lübbe, 1999）から重訳された ものである。オリジナルは三部作で，中村喜春『江戸っ子芸者一代記』(草思社，1983 年), 『江戸っ 子芸者一代記 戦後篇』(草思社, 1987 年), 『江戸っ子芸者一代記 アメリカ篇』(草思社, 1987 年) であるが，ロシア語訳は一冊にまとめられている。

(4) オルガ・ラゾレワは公式には 1966 年生まれであるが, 実は1957 年である。作家はノン・ノンフィク ションも書き，その際には作者自身がラゾレワの名前で語り手として登場するが，想定される読者の 年齢に合わせて，語り手である自分の年齢も偽ったと作者自身は説明している（2009年 5 月 27 日の ラゾレワと筆者の通信による)。

(5)『ロシア人芸者』の三部作は『ロシア人芸者の回想録』(Мемуары русской гейши, 2006), 『ロシア人 芸者の帰還』(Возврашение русской гейши, 2007), 『ロ シア人芸者の没落』(Падение русской гейшu, 2007) とともに三部作を構成する。なお，2009年の再版の際に三部作のタイトルは「ロシア人 芸者 回想録」(Русская гейша. Мемуары), 『ロシア人芸者 帰還』(Русская гейша. Возвращение), 『ロシア人芸者 誘拐』(Русская гейша. Похищение) となっている。本稿では, 三部作の全作を指 して『ロシア人芸者』と表記する。 
きな要素になっている。ラゾレワ自身は, アーサー・ゴールデンの『さゆり』やその映画化の ロシアでの成功に刺激された出版社に執筆を依頼されて『ロシア人芸者』を書き，また，別に 中村喜春の『江戸っ子芸者一代記』からも影響を受けたと述べている ${ }^{(6)}$ 。しかし, 作品を検 討してみると，単にそれらの作品に描かれた芸者の表象を再利用したのではない。『ロシア人 芸者』の主人公は，日本人ではなく，四分の一日本人の血が入ったロシア人であり，芸者のイ メージに新たな側面が加えられているのである。日露混血の芸者といらょらな表象をロシア人 である作者がなぜ作り出そうとしたのかを検討することによって, 現代ロシアに打ける日本趣 味の中に，単なるエキゾチズムやオリエンタリズムではなく—つまり，ロシア人から見れ ば，「他者」である日本の表象だけでなく一人種や文化の横断面に析出する，ロシア人の新 しい自己表象が浮かび上がってくるのではないか。本論文では, そのような観点から，『ロシ ア人芸者』三部作を中心とし, 現代ロシア文学に括ける芸者の表象, その特徵, そして役割を 考察する。

\section{1 芸者イコール売春婦というステレオタイプ}

\section{（1）ロシア人から見た芸者像}

まず，三部作のあらすじを簡単に述べると，主人公であるターニャは，四分の一日本人の血 が入った混血ロシア人であるが, ある日, 恋人のピョートルが仕事の関係で東京に行くことに なる。ちょらどその時, 地下鉄サリン事件が起こる。ピョートルはオウム真理教の一員で，そ らとは知らないままにサリン事件に関与してしまい, 罪悪感のため割腹自殺をする。ターニャ は, ピョートルを入信させた人々が彼を犯罪に怙いやったのだと考えるよらになり，彼らに接 近する手段として芸者になることに決め, 修行をつみ, 「ロシア人芸者」として日本で売り出 す。ロシアに帰ってからは「芸者クラブ」を始めて, ロシア人やロシア訪問中の日本人のパー ティーを芸者として勤める。続く第二作・第三作でも，アヤメといら名で芸者稼業をするター ニャの様々な恋愛や肉体関係が描かれるが, それを通じて, 芸者の歴史・特徵などの日本の文 化に関する情報がふんだんに提供される。

『ロシア人芸者』はそもそも出版社の依頼に基づいて執筆されたものだが，最初は「ビスト ロフ出版」(“Быстров”) の「不道徳の街」(Город греха) といらシリーズに, ほかの作品も 含めて, ラゾレワのほとんどの作品は収められていた。それらは, その後, エクスモ出版社 (“Эксмо”) の「エロスの時代」（Эра Эроса）といらシリーズのタイトルとして再出版された のだが, 叢書のタイトルから判断しても, 出版社は芸者の表象を通じて日本のエキゾチズムと セクシュアリティをアピールしょらとしていたことが明らかである。『ロシア人芸者』の主人 公ターニャは客と性的関係をもち, サドマゾヒズムを含めた性技を芸者のわざの一つとしてお り, 作中では性的な魅力や能力が芸者の重要な側面を構成しているという考光がはっきりと表 明されている。芸者は一般に西洋では，オリエントの女性のセクシュアリティを代表する表象 となっていると同時に，売春婦のイメージとしばしば重ね合わせて描写されてきたが，ラン゙レ ワはそのよらな伝統を十分に認識した上で，彼女自身の「芸者」像を作り出したのである。 ターニャがモスクワで「芸者」として活動していた時，こう述懐する。「私たち「ターニャら

(6) 2009 年 5 月 25 日のラゾレワとの通信による。 
芸者]が舞台に出ると, 叫び声や拍手が起こった。演目がすむと, 私達はホールのあちこちに 散って，仕事を始めた。男たちは興味深そうにわたしたちと歓談したけれぞ，女性は用心深そ らだった。私たちの社会ではいまだに，芸者は日本の売春婦だといら意見が存在することを 知っていた。私たちの演技だけで，この確固たるステレオタイプを壊すのは難しかった。巨大 なモスクワにとって，私たちは砂漠の砂粒のよらなものだった。」(7) 芸者クラブの経営者でも あるターニャは一そそれは作者ラゾレワの意見でもあろら——シアに打ける芸者の人気は工 キゾチズムに皃とんど由来して抢り，また，実体は売春婦だといら誤解がはびこり，「芸者」 というものの本質に関する正しい理解がないとこぼしている。だが，先の引用からも分かるよ らに，芸者が売春婦だといらステレオタイプがあるとしても，男性と女性の間ではそれに対す る態度は異なる。ロシア人男性はこのステレオタイプに基づき芸者を賛美するが，女性の方 は，芸者を売春婦として軽薷しながら，脄妬心に近い，複雑な感情も持っているのである。

\section{（2）芸者と水揚げの習慣の問題}

芸者と売春婦の共通点と相違点は，水揚げの習慣に集約して表現されていると言えよう。ラ ゾレワの小説でもこの問題は非常に重要である。前述のように, 『ロシア人芸者』においては, ラン゙レワはゴールデンと中村喜春の影響を強く受けたが，この二人の作者の影響は特に水揚げ の習慣をめぐって見られる。

ゴールデンの『さゆり』が出版された後, モデルであった岩崎峰子は, ゴールデンの小説で は，芸者に関する記述が事実と違っていると主張した。とりわけ，ゴールデンは水揚げを，処 女性を売る行為として描写したが，岩崎はこれを事実の歪曲だと言い，芸者を売春婦として描 き出したことに抗議し, 果てには訴訟まで起こした。本当の祇園の芸者は処女性を売ったりす るわけなどなく,「水揚げ」といら言葉は, 祇園の芸者の中では, 単に収入の意味で使らのだ と岩崎は言う。芸者は抢金のために性的関係を持つことはないのに, そのような䛊解が西洋に は広く存在し，ゴールデンも間違った観念を受け継いでいるというのである ${ }^{(8)}$ 。

水揚げについてであるが，ラゾレワは第一作ではその問題に言及していない。したがって， 第一作からだけでは，ラゾレワが水揚げを売春行為だと思っているのかぞらかは分からない。 第一作で「水揚げ」の描写が出てこない理由は, 単に主人公のターニャ自身が処女ではないた めかとも思われる。ところが，第二作および第三作では，水揚げの問題が繰り返して言及され ている。ターニャの芸者クラブの一員であるリタが処女であるという設定になっているが, 「水揚げ」といらテーマを導入するための操作であったのだろう。では，そのことでラゾレワ は一体，何を示そらとしていたのであららか。

一般に水揚げは「処女性の売却」といら典型的な売春行為だと考兄られており，ロシア人も そのような理解をしている。そこで，「水揚げ」という習慣は，芸者すなわち売春婦であると みな寸大きな根拠となっているわけである。

ラゾレワも，ゴールデンと同じく，処女性の売却という意味での「水揚げ」が制度として存 在していることを認めているょらである。だが，「水揚げ」の描写に当たって，ラン゙レワは ゴールデンょりも中村をむしろ参考にしていたよらに思われる。といらのも，なぜなら中村の

(7) Лазорева, Ольга, Русская гейша. Возвращение, Москва: Эксмо Яуза, 2008, стр. 137-138.

(8) Prasso, Sheridan, The Asian Mystique: Dragon Ladies, Geisha Girls \& Our Fantasies of Exotic Orient, New York: Public Affairs, 2006, pp. 208-209. 
自叙伝の中でも, 水揚げといら習慣についての説明があり, 主人公がその問題に直面する場面 があるが，彼女は結局，処女性を売ることを選ばず，好きな男性に処女をささげることにす る。ラゾレワの小説でも, 水揚げをめぐる事態は同じょらに展開する。つまり, 処女である登 場人物のリタは，東京で芸者をすることにするが，水揚げを避けるため， ロシアに帰って，恋 人に処女をささげることに決める。こうしたプロットの展開には, 売春行為としての水揚げ の, 芸者の職務に拈ける意味づけを大きくトーンダウンさせようといら意図が感じられる。結 局，『ロシア人芸者』の中では，水揚げの習慣が日本に存在していることは否定されていない のだが，芸者の自由意志によってこの習慣にしたがってもよいし，したがわなくてもよいとい らことが強調されることによって, 芸者を売春婦とみなす大きな根拠になっている水揚げの売 春行為としての性格は大いにトーンダウンしているといえよう。そして, その点をさらに強調 するため，ラゾレワは日本と香港を比較する。

\section{（3）香港を舞台とした芸者と売春婦の対照}

第三作で主人公のターニャとリタは誘拐され，香港に売春婦として売られる。誘拐者はター ニャが芸者であることに気付き，彼女を芸者として置屋に送りこむが，そこでは水揚げは，日 本と違って強制力があり，全ての香港芸者は処女性を販売しなければならない。ターニャとリ タが香港の置屋に芸者として勤めはじめると, 中国人の置屋の主人はリタの処女性を売る交渉 を始め，乙かも，それを小出しに売ることにする。つまり，まずは客とアナルセックスをさせ て，その次に「本来の」処女性を売る予定にするのである。

ラゾレワが香港を舞台にして，「中国」といらモチーフを導入したことについては，いくつ かの理由が考えられる。ラン゙レワは，日本の性的な習慣についての文章を各種，引用している が，第三作では，日本の伝統や習慣の多くは，もともと中国から取り入れられたといらことが 書かれて打り，この作品では，中国の性の習慣についての解説が，日本のそれについてょり多 い。そこで，作者は舞台もそれに合わせたのだと思われる。実際，三作を通じて，作品の舞台 設定は重要な役割を果たしている。例えば，第二作では，パリが舞台となり，ジャポニスムが 紹介されている。フランスで構成された芸者のイメージは, ロシアに打けるイメージ形成に重 要な役割を果たしており，第二作の舞台設定はそれへの言及になっているわけである。

さらに，ラゾレワは芸者についての情報を集めた際に，利用していたのはアンドレィ・フェ シュン（Андрей Фесюн）の吉原に関する一連の「著作」（2003）(9) である。実は，フェシュ ンの「著書」そのものが，スティーヴン・ロングストリート执よびィーサル・ロングストリー ト（Stephen, Ethel Longstreet）の『吉原—芸者, 売春婦と古い日本の遊郭』（Yoshiwara: Geishas, Courtesans, And The Pleasure Quarters of Old Japan, 1970）の部分的な翻訳であるが, ロシア語しか出来ないラゾレワは，フェシュンの翻訳を参照したと考えられる。ラン゙レワと フェシュンのテキストを比較すると，全く同じょうな文章が見られ，そのことは明らかであ

(9) Фесюн, Андрей. Ёсивара.（27/11/2003-03/01/2005）この文章は様々なサイト（たとえば http://www. japon.ru/?TextArchive\&ID=159, http://cssc.narod.ru）に出て招り, 出版社 Издательство “ВРС” の出版

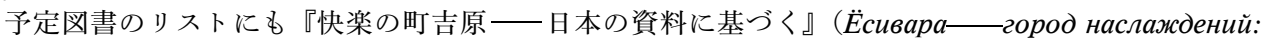
по материалам японских источников）として掲載されている。しかし，リストには日付がないた め, すでに出版されたのか, だとすれば, いつ出版されたのか, それとも今後, 出版予定なのか不詳 である。筆者が調べた限りでは, 当該図書はまだ出版されていない。http://www.mipco.com/ ListovkaUKF.pdf。なお，ロングストリートは芸者と遊女をはっきり区別せずに論を進めている。 
る。だが，ラン゙レワは単にフェシュンが提供した個別の情報を利用しただけでなく，作品の テーマや展開の上でも参考にしたと思われる。フェシュンによれば「営業の現場で働く売春 婦，使用人を管理し，職場がうまくいっているか，いかないかを見張っていたのは，㧤ばさん [やり手婆のことであろら——筆者］と呼ばれる，たくましい中年の女であった。（中略）彼女 達は［客には］打辞儀したり，にこにこしたりしていたが，女中も遊女も，おばさんは厳しく， 残酷で，あらさがしばかりしている監察者だと分かっていた。（中略）規則を破ったり，㧤ば さんを怒らせたりした女中や遊女に対する罰は過酷であった。低級の売春宿の管理人はしばし ばサディストであった。(10) ラゾレワは，ここで示されている，売春宿のやり手婆をサディス トと見なす見方に刺激を受けたのだろう。芸者のイメージはしばしばサドマゾヒズムを扱った ポルノ映画でも利用されて招り，「奴隷」である芸者と「主人」である置屋の主人・管理人の 関係が描写されている。こうしてフェシュンは芸者が奴隷のように扱われているさまを描くわ けだが，このような概念は「芸者奴隷」(geisha slave) という用語として，サドマゾヒズム文 献では広く使われているものである ${ }^{(11)}$ 。ラン゙レワは売春婦ではなく，また置屋の支配下にあ るのでもない, ロシアで独立して営業する芸者を描いたが，一方で，サドマゾヒスティックな 描写にも興味があり, 支配され，㛜しく管理されているような芸者を描きたかったのであろ う。しかし, 彼女は『ロシア人芸者』を執筆する過程で, 最初は明らかに日本に対して批判的 な目線を持ち，日本人も否定的に描写したのだが，次第に日本賛美を強めるようになり，ロン グストリート/フェシュン流に, 日本の芸者を性的奴隷のように描きたくはなかったのであろ う。そこで舞台を香港に移すことが要請されたのである ${ }^{(12)}$ 。第三作では, 日本人の優れた習 慣, 芸者のすばらしさが賛美されているのに対し, 香港に拈ける芸者の置屋は批判的に描写さ れている。そこでは，置屋の主人の娘はサディストとして振る舞い，まさにフェシュンが描い た吉原の遊女や芸者とそっくりの事情がそこに見られるのである。ラン゙レワの小説を見ると， 香港の置屋のデン婆とターニャの関係自体は性的なものではないが, ターニャはしばしばその 不作法な振舞いのためデン婆に罰され，その関係は，上記に取り上げたような SM 小説や映画 のモチーフに酷似している。例えば, ターニャに対する罰の一つは, 次のよらな「影の演劇」 のパフォーマンスに参加させることである。ターニャは最初に男ばかりの客にカードを配る。 その後，上半身を見えないよらに黒い服を着せられ，下半身は裸のままそこに残らされ，同じ ように上半身だけ隠している男女と客がいる部屋に入る。そのまま, 上半身着衣, 下半身脱衣 の参加者は舞台の上で性交するが，それだけでなく，ターニャにカードを貪った客も参加し， ターニャと性交することができる。この種のゲームはSM 文学, SM 映画によく出るモチーフ である。

だが，香港を舞台に選んだのは，単に作家の中国人や中国社会に対する差別のためでもなけ

(10) Longstreet, Stephen; Longstreet, Ethel, Yoshiwara: Geishas, Courtesans, And The Pleasure Quarters of Old Japan. Tokyo: Tuttle Publishing, 2009, p. 104.

(11) この表現は, Geisha Slave（1985）というビデオに発するもので，それは「奴隷」である芸者と，そ の「主人」である女性がサドマゾヒズムのロール・プレイやファンタジーにふけるといら内容になっ ている。Murray Thomas E.; Murrell Thomas R., The Language of Sadomasochism. A Glossary and Linguistic Analysis, New York: Greenwood Press, 1989, p. 75.

(12) 芸者や遊女の悲惨な生活については，ラゾレワが影響を受けたゴールデンの小説にも記述があるが, 『ロシア人芸者 誘拐』の中で, 香港の置屋の管理人について主人公が発している「サドマゾ」とい ら表現を見ると，ラゾレワのこの点に関するインスピレーションの源泉は，ゴールデンではなく，む しろフェシュン/ロングストリートであるように推測される。 
れば，偶然の産物でもない。

1990 年代, ソ連崩壊後, ロシアとマカオや香港の関係が強くなり, ロシアのマフィアはマ カオ，香港，マレーシア，上海の組織と組んで活動しょらといら傾向が見られた。そのような 協力はマカオとの間でもっとも強く, 2002 年までマカオはロシアの麻薬の販売のハブとも なった。また，上記の国では，ロシア人の売春婦やストリッパーがエキゾチックなものとして 捉えられ，大人気であったため，売春目的の人身売買が広く行われた。90年代に，毎年何千 人もの女性が不法に売春に従事する目的で渡航し, または誘拐されて, 様々なアジアの国に 行ったが，その目的地の中では，マカオと香港が際立っている(13)。ラゾレワの小説の中では, ロシアのマフィアは「黒い頭蓋」と呼ばれて拈り，中国の「三合会」と関係があることになっ ている ${ }^{(14)}$ 。1949 年以降「三合会」の拠点は香港であるので ${ }^{(15)}$, そのため, 第三作の舞台は 香港にされたのであろら。

このよらな背景を見ると，ラゾレワは，現実に行われていたロシアのマフィアと香港の関係 を小説に利用し，売春婦としての芸者の生活の厳しい状況と香港の人身売買と結びつけ，第三 作のあらすじを形成したのだと考えることができよう。そこでは，一見したところ，日本人と 中国人の描き方の違いは，単に人種や国籍の違いによるものだとも見えるが，実は歴史的な事 情を背景にしたものであることが分かる。ラン゙レワは第三作では香港における「芸者」のあり 方を，日本のそれとたびたび比較し，違いを強調している。こうして，香港に拈ける売春業の 現実の歴史を利用して，ラゾレワは，日本の芸者が売春婦ではないことを明確にしているので ある。

しかし，芸者と売春婦の区別を考える時，ラゾレワの『ロシア人芸者』においては，日本と 中国の対比だけでなく， ロシア人の女性と［日本人の］芸者の対比も描かれているので，次に それを検討したい。

\section{2 芸者とロシア人女性の対比}

すでに示してきたよらに，ラゾレワは，ロシア人には「芸者」の性質に関する正しい理解が ない，つまり，誤って売春婦だと見なしていると主張してきているが，しかし，作品の中で は，ロシア人 (女性) が芸者をあからさまに批判する場面は多くない。それぞころか，ロシア 人女性については, その芸者願望も描き出されている。ここには, ロシア人女性の芸者観が示 されているだけではなく，ラゾレワの見るところの， ロシア人女性そのものの特性—つま り，彼らの方が逆に持っている娼婦性一一が表現されているのだといえよう。ラン゙レワのこう したロシア人女性批判の中に，彼女が作り出そらとした主人公の芸者像の性質が明らかになる ように思われる。例えば，金のために男性と付き合っているロシア人の女性と，芸者としての ターニャは対照的に描かれ，ロシア社会が批判され，日本人の方が理想化されることになる。 このような，芸者であるターニャとロシア人の女性の対照的な描写は三部作を通じて描かれて

(13) Share, Michael B. E., Where Empires Collided: Russian and Soviet Relations With Hong Kong, Taiwan, and Macao, Hong Kong: Chinese Univ. Press, 2007, pp. 252-253.

(14) Лазорева, Ольга, Русская гейша. Похищение, Москва: Эксмо Яуза, 2008, стр. 146.

(15) 詳しい情報は Hutton, Christopher; Kingslay, Bolton, Triad Societies: Western Accounts of the History, Sociology and Linguistics of Chinese Secret Societies (Colonial Encounters) Vol .6, New York: Routledge, 2000 . 
いるので，重要な役割を果たしていると思われる。たとえば，ターニャはロシアで芸者クラブ を設立する際に，「もら何人もの，将来ものになりそらな女の子と別れなくてはならなくなっ た。といらのも，みんな，一晚かぎりの，金持ちの拈客を探そうとするもんだからね」(16) と こぼす。また，「しかし，動き手を見つけるのがひどく難しかった。女の子は広告に応えて集 まったが，ほとんどみんな修行中にやめてまった。その上に，われわれロシア人は，まだまだ 芸者と売春婦を結びつけて考えていた。それで, 面接の時に, らちの事務所は肉体的なサービ スを提供しないし，修行はずっと続け，毎日，挆稽古しないといけないと告げると，多くの希 望者はさっさと立ち上がって，帰ってしまった」(17) ともターニャは言ら。ロシア人の女性は 芸者と売春婦の区別をしないため，芸者をすることを，簡単に打金を稼ぐ方法としかみなして いないとされるのである。

こうした描写からは, ペレーヴィン（Виктор Пелевин）（1962-）の『チャパーエフと空虚』 (18)（Yanaeв и Пyстота, 1996）が想起される。この小説の第 6 章では, カワバタといら日本 人が登場し, 七ルジュークといら登場人物に [セルジュークの妄想の中で, または現実に］「面 接」をするが，性的な次元で知り合うことが大切だとカワバタが主張し ${ }^{(19)}$, 女性を面接の場 に招きいれ，二人がその女性達と性交する場面がある。その女性達は日本人でもなく，芸者で もないが，着物めいた服を着て，日本人の格好をしているロシア人売春婦である。ここでは， 明らかに低級娼婦であるロシア人が日本人の格好をして，日本人，そして，日本人の客である ロシア人に性的に利用されるわけで，ロシア人女性は非常に批判的に取り扱われている。

一方，ラン゙レワの小説では，日本人は扔金持ちだといらイメージがあり，ロシア人女性はそ のような目的で—つまり，日本人に体を売って，簡単に大金を稼ぐために一一芸者になりた いのだといら解釈が与えられている。こうした，金づるとしての日本人男性とロシア人女性の 関係の描写からは， ウラジーミル・クーニン（Владимир Кунин）（1927-）の大七ットとなっ た『インターナショナル・ガール』(Интердевочка, 1988）想起されるであろう ${ }^{(20)}$ ○イン ターナショナル・ガール」は芸者でもなく, 普通の売春婦でもなく, 外国人客用, つまり外国 通貨で自分を売る売春婦である。この小説をめぐっては, 種々の解釈があるが, 売春婦の姿を 通じて, ソ連時代に拈ける, 資本主義批判が表現されたといらような評価もあれば, 売春婦そ のものがソ連の象徵となり, ソ連時代の国家や国民の状況, または女性の社会的地位が批判的 に描かれたのだとする評者もいる。このように解釈に差異はあるものの，大抵の場合には， 『インターナショナル・ガール』の中心をなす売春婦の物語は, 単なる風俗世界の描写ではな く，国家や社会の状況，またイデオロギーの象徵となっているといらょらな指摘がなされてい

(16) 前掲, Лазорева, Ольга, Русская гейша. Возврашение, стр. 322.

(17) 前掲, Лазорева, Ольга, Русская гейша. Похищение, стр. 8.

(18)『チャパーエフとプストタ』と訳される場合もあるが, ここでは 2007 年に群像社から出版された三浦 岳の訳『チャパーエフと空虚』のタイトルに拠る。

(19) Пелевин, Виктор, Чапаев и Пустота. Москва: Эксмо, 2009, стр. 258.

(20) この小説は 1989 年にソ連やスウェーデンの共同製作で同じタイトルで映画化され，大ヒットになっ たが, 日本では, 『令噻ターニャ』として知られている。ロシア語のタイトルは, 作者による新造語 である。国際と女性といら言葉を一緒にし，外国人の客と交際する売春婦といら意味で「国際女性」 といら言葉を使ったのである。クーニンの小説以降に, この言葉は一般的に, 外国人の客と付き合 う，普通の売春婦より高いレベルの売春婦を示すようため使われるようになった。

(21) 詳しくは, Borenstein, Eliot, Overkill. Sex and Violence in Contemporary Russian Popular Culture, Ithaca and London: Cornell University Press, 2008, p. 85-87. 
る ${ }^{(21)}$ 。しかし, ここで重要なのは, 日本人の男性とロシア人の女性の関係で象徵される日本 とロシアの力関係である。『インターナショナル・ガール』では，イチロウ・カネダといら日 本人の客は，「もちろんすごくよく払った。ほかの日本人みんなと同じょうに」(22)などという 言辞を弄して抢り，バブル期の日本人の太っ腹さかげんが強調されている。そして，ロシア人 の女性といえば，外国人（しかもここでは，日本人であることは重要である）に身を売る，男 性に依存する哀れな存在として描かれている。ペレストロイカ時代の社会状況を反映した物語 だと言えるが，経済的にロシアは日本より低い位置であったため，日本人に対するある種の劣 等感や依存心が表現されていた。

そして，ラン゙レワの『ロシア人芸者』に扔いて，ロシア人女性が日本人男性を打金の対象に する話に戻ると，ラゾレワの小説が出版された 2006 年においても，日本は依然として経済的 に数段, 高い位置にあり, 打金の対象となるので, 『インターナショナル・ガール』の売春婦 であるターニャと同じょらに，安易な金稼ぎの手段として日本人と付き合いたがっている「口 シア人芸者」を描き出すことによって，ラゾレワはとのような社会情勢を批判するのである。

リンネ・アトウッド（Lynn Atwood）の “Sex and Cinema” (23) といら論文によれば，ソ連時代 に，男女平等は公式な政策とされていたのにも関わらず，男女差別は現実であった。そのよう な傾向はソ連が崩壊した後にも続いたが, その中で, 経済的であれ, 精神的であれ, 肉体・性 的であれ，男性への依存から脱却した女性を描こうという傾向が見られるようになった。アト ウッドはこうした傾向を，映画を題材にして述べているが，同じょらなことは小説にも当ては まる。レナ・ゴシロ (Helena Goscilo) はリュドミーラ・ペトルシェフスカヤ (Людмила Петрушевская, 1938-) やリュドミーラ・ウリッカヤ (Людмила Улицкая, 1943-) らの女性 作家を取り上げ，性的な表象によって，「男性の視線」にからめとられた女性のあり方から逃 れよらとした女性作家の作品の分析をしている ${ }^{(24)}$ 。ロザリンダ・マーシュ（Rosalind J. Marsh）が指摘するように, グラスノスチ以降, ロシア人女性作家はロシア社会に深く埋め込 まれた，固定的な性的役割からある程度に自由になった ${ }^{(25)}$ 。それは，ラゾレワが書いている ようなエンターテインメント系の作品にも表れているのである。「ロシア芸者」ターニャは, アレクサンドラ・マリーニナ（Александра Маринина, 1957-）の探偵小説の主人公アナスタ シア・カメンスカヤ——彼女はソ連時代にあって，当時の典型的な夫婦間の役割を転倒させよ うとし，そのことで，男性に頼らない女性表象を具現した——の，現代における後継者だとも いえよう。ラゾレワはターニャという，ある意味で自立した女性を描くことで，売春婦，また は，売春婦のように男性に依存するロシア女性を批判したのである。

(22) Кунин, Владимир, Интердевочка, Москва: АСТ Хранитель, 2007, стр. 58.

(23) Attwood, Lynne, "Sex and Cinema," in Kon, Igor; Riordan, James, eds., Sex and Russian Society, London: Pluto Press, 1993, pp. 81-83.

(24) ゴシロは様々な視点からペレストロイカ以降のロシア人女性の自己認識・主張, そして文学を考察 し，フェミニズムの展開，「女性文学」の問題点などに注目し，ロシア人女性が，男性に見られる対 象から離脱するさまを分析している。そのような女性（作家）の試みは必ずしも成功したわけではな いが，本論文では，その女性作家の試みそのものが重要であることを指摘するにとどめる。詳しく は, Goscilo, Helena, Dehexing Sex: Russian Womanhood During and After Glasnost, Michigan: The University of Michigan Press, 1996.

(25) Marsh, Rosalind J., "Introduction: New perspectives on women and gender in Russian Literature," in Marsh, Rosalind J., ed., Gender and Russian Literature: New Perspectives, Cambridge: Cambridge University Press, 1996. 


\section{3 男性に依存しないロシア人女性の表象}

では,ターニャはどのような意味で「自立」していたのか。まずは，ターニャの経済的な状 況を見ると, ターニャは, 恋人のピョートルが死んだ後, 大金を遺産として受け取り,さらに 彼のアパートも相続する。また，性的関係のあるなしに関わらず，客から様々なプレゼント， 例えば，何万ドルもの值段がする黒真珠のネックレスなどを貴う。旦那であるイトウサンから は，芸者に必要ないろいろなもの，例えば，着物，扇子，三味線などを贈ってもらら。そこで は, 『インターナショナル・ガール』のよらに，性交することで扮金を貪らのではなく，ラゾ レワは，ターニャを経済的なチャンスを自らの才覚で垷みとるよらな女性として描くのであ る。他方，自ら望めば，性的関係を持つこともあり，何人かの客や旦那の役割を果たしている イトウさんなどの日本人とは床をともにしている。主人公ターニャは, 自分の選択で日本人男 性と性的な関係を持つのである。「[芸者は］客と寝ないといけないわけではない。彼女は男の 連中といて，彼らの余层を美化しさえすればいい。」(26)このような主張は，『ロシア人芸者』 三部作を通じて繰り返されて抢り，芸者は売春婦ではないということが明確にされている。 ターニャも芸者が必ずしも客と性的な関係を持つ必要がないと強調する。そして, 芸者の性的 な魅力や能力は, 芸者を売春婦にするのではなく, 芸術としてのセクシュアリティを体現す る, 理想的な女性にするのだと主張している。こうして三部作には, 西洋ではしばしば売春婦 と見なされている芸者のステレオタイプを変えようとする意図が観察されるのである。一方， 日本人の方は，「芸者」の真価が分かっていることになっているので，ターニャに対しても尊 敬をもって振舞い, プレゼントを贈ったりして, なにかと気にかける。こうした好意ある振る 舞いは, 性行為に対する代償ではなく, 単に, 特別な女性・芸者であるターニャに対する好意 の表現として描写されている。何も依頼しないし, 男につくすわけでもなく, 何の犠牲も払わ ないが，それでもなんでも男にしてもらえるという，作家ラゾレワにとっての理想を具現する 女性像がこうして作り出される。経済的にも, 性的にも自由である女性の典型として, 芸者は 立ち現れたのである。もちろん, ターニャの自立は彼女の性的な魅力に究極的には拠ってお り, 男性の政治的・経済的権力と, ジェンダー間の力関係は保持されているといら批判は可能 である。だが，性の美学とでもいうべきものを通じての，支配関係の転倒への契機が，少なく ともイメージとして示されていることも事実である。こうして『インターナショナル・ガー ル』に描写された売春婦同様, 男性に依存し, 支配されるロシア人女性像を超克するイメージ として, ラゾレワは独自の芸者像を作り上げ, 作品を構成した。ラゾレワの小説において, 芸 者の表象は, 他者である日本人のエキゾチズムを描くためのものだけではなく, ロシア人の女 性の新しい表象を作り上げるためのものだったのである。

小川さくえは『菊さん』に関して，「そこに描かれた日本女性の形象が，語り手の変幻す る愛憎, 失望や怒りといら感情的なフィルターを経て造形されたものである」(27) と述べてい る。一人称の叙述である『扣菊さん』の場合, 語り手と作者は必ずしも重ならないが，それで も日本女性の形象は, ある意味で, ロティといら男性作家のフィルターを通して作られたもの といえる。『ロシア芸者』の場合は三人称叙述の形式をとって扣り，ここでも，ラゾレワとい

(26) 前掲, Лазорева, Ольга, Мемуары русской гейши, стр. 229.

(27) 小川さくえ『オリエンタリズムとジェンダー——「蝶々夫人」の系譜』法政大学出版局, 2007 年, 27 ページ。 
ら女性作者がターニャといら女性の語り手を使って, 女性の視点から日本女性の形象を作り上 げたといら面がよりはっきりしている。

ロシア人捕虜たちの著書であれ，ヴァレンチン・ピークリ（Валентин Пикуль, 1928-1990) の『オキヌさんの物語』（Три возраста Окини-сан, 1985）などであれ，ロシア文学における 日本人の表象はほとんど男性作家の手になるものであるから，「男性の視線」(male gaze) が 重要な役割を果たしていると思われる。それに対して, ラゾレワは女性の視点から女性を描写 する。言い換えれば，ロティ，ピークリをはじめ，文学においてずっと男性視点から見られ， 形成された，残酷な日本人男性に対して，可愛い人形でありながら，同時に見返りに金銭を要 求する「ムスメ」の像は，ラン゙レワの三部作に括いて，女性作家の視点の導入や，そこに込め られた，男性に依存する女性像を打ち破ろらとする意図によって，受動的な人形，そして否定 的なムスメ・売春婦の表象としてではなく, 逆に肯定的な, 性的に, また経済的に自立した女 性像として立ち現れてきたのである。

そして, 日本人の芸者ではなく, 日本人の血が入っているロシア人の芸者を作り上げた理由 を考劣ると, ロシア人を表象するため, そしてロシア人の読者が小説に描かれた女性を自分に ひきつけて見ることができるょうに，日本人ではなく，普通のロシア人とも違った，八ィブ リッドなロシア人の主人公が要請されていたのだと考えることができるだろう。

橋本順光は，1896 年にイギリスで上演された『芸者』について，このオペレッタがイギリ ス人に，彼らの期待に沿らような「日本」を経験する機会を与え，そのために非常に人気が あったのだとしている ${ }^{(28)}$ 。この「日本」は実はイギリスの謂だったのである。『ロシア人芸者』 でも同じよらな戦略が取られたのであろら。ロシア人の読者は，半分日本人である主人公を通 じて「芸者」や「日本」を経験できたのだが，残り半分ロシア人である主人公は，それが実は 「ロシア人女性」のことであり，「ロシア」のことであることが分かる仕掛けになっていたので ある。

\section{終わりに}

溝㴊園子は「V・ピークリ『オキヌさんの物語』論」で「最近の作品には, 日本人女性が登

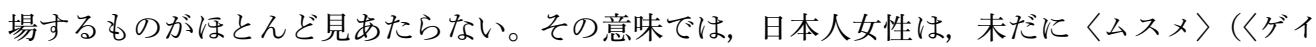
シャ〉）として保管されている，あるいは新たなイメージ化の前段階にあると考劣られる」(29) と指摘した。2003 年に出版されたボリス・アクーニン（Борис Акунин, 1956-）の『金剛乗』 (Алмазнал колеснииа) に登場する日本人女性を考えても，日本人の女性が取り上げられる作

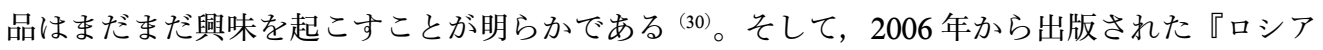

(28) Hashimoto, Yorimitsu, "Japanese Tea Party: Representations of Victorian Paradise and Playground in The Geisha (1896), " in John K. Walton, ed., Histories of Tourism: Representation, Identity and Conflict, Clevedon: Channel View Publications, 2005, p. 104.

(29) 溝㴊園子「V・ピークリ『オキヌさんの物語』論」『文学部論叢』第 79 号, 熊本大学文学会, 2003 年 3 月, 117 ページ。

(30)『金剛乗』に登場する日本人女性は売春婦や忍者の娘であり, 日本学者でもあるアクーニンは典型的 な日本人女性の表象に意図的にねじれを加えてわけである。アクーニンの操作は文化的に興味深く, 稿を改めて論じたい。なお，溝渕の論文は 2003 年 3 月に, アクーニンの小説は同年 12 月に出版され ているため，溝㴊はアクーニンの小説について言及していないが，『金剛乗』を考慮に入れても，「最 近のロシア文学の作品に日本女性が登場するものがほとんどない」といら溝㴊の主張は否定されはし ないであろう。 
人芸者』三部作を見ると，日本人のイメージにはいまだ芸者との関連が強いものの，ラゾレワ によって, 芸者は単にエキン゙チックな「他者」を表すものだけではなく, ペレストロイカ以降 のロシアの経済状況, それに関わる売春婦の問題, 女性の位置など, ロシア固有の問題を表現 するために利用されたことが理解されるであろう。作家は売春婦ではない芸者の表象を使っ て，男性に依存しない自分なりの，ロシアの理想的な女性を表象しょうとした。一見したとこ ろでは，自分の欲望を他者である日本に投影して，ラゾレワは典型的なオリエンタリズムの作 品を書いたと考えることもできるし，「理想的な女性」とはもっぱら男性に依存することから 自由になれず，完全にジェンダ一問題から破裂できなかったと批判もできる。しかし，このよ らな性的・経済的に自由な芸者の表象を通じて，ラゾレワは，オリエントのセクシュアリティ を象徵する芸者を欲望の対象とする西洋の男性と, 服従するオリエントの女性との一般的な関 係を脱構築しているかに見える。「欧米と日本，ひいては欧米とアジアの関係は，「征服者＝男 性」と「征服される者＝女性」の関係として描かれるのが普通である」(31) と小川さくえは『お 菊さん』について述べているが，ラゾレワではとれとは逆の関係が描かれており, 同時に東洋 人でも西洋人でもある女性を芸者として描き出すことで, オリエンタリスティックな支配構造 が相対化し，複雑化しているのである。

ゴシロによれば, ジェンダーの領域に捻いては, ポスト・コミュニズムのロシア社会の解説 者たちは, 共産主義社会からの断絶より継続の証拠を示し続けているが, 数少ないロシアの フェミニストは西欧のフェミニズムに支援を求めつつ, ロシアの女性の生活だけでなく, ロシ ア文化のレトリックにペレストロイカを引き起こそらとしている(32)。『ロシア人芸者』を見る と, ラゾレワは欧米ではなく，日本文化に目を向け，解放の契機を探ったのだといえよう。し かも，その契機となった「芸者」は，日本人を代表するものではなく，日露混血といらハイブ リッドな女性を表象したものであり，溝渕が指摘するような，ロシア文学における，新たな日 本人女性のイメージがここには予感されるのである。

（本論は複数レフェリーの審査を経て編集委員会が採択したものである。）

(31) 前掲，小川さくえ『オリエンタリズムとジェンダー——蝶々夫人」の系譜』 29 ページ。

(32) 前掲, Goscilo, Helena, Dehexing Sex: Russian Womanhood During and After Glasnost, p. 49. 